\title{
Chromosome count and karyotype study on endemic species Silene schimperiana Boiss. (Caryophyllaceae), Sinai, Egypt.
}

\author{
Abbas A. El-Ghamery, Mohammed M. Morsy and Mahmoud S. Abu-Shahba* \\ Botany Department, Faculty of Science, University of Al-Azhar, Egypt. \\ *Corresponding author: mahmoudsaqr85@live.com
}

\begin{abstract}
:
Chromosome count and karyotype study were performed on the available nine populations of the endangered endemic species Silene schimperiana Boiss., section-Sclerocalycinae (Family: Caryophyllaceae), recorded only in a few localities in Sinai Peninsula, Egypt. The species studied showed chromosome number $2 n=2 x=24$ for the first time in Egypt. The populations studied of $S$. schimperiana showed significant values of Pearson's correlation according to karyotypic characters. The cluster analysis based on karyotypic characters divided the studied populations into two groups with $92 \%$ similarity coefficient.
\end{abstract}

Key words: Karyotype, Silene schimperiana, Chromosome number, Chromosome count, Sinai, Egypt

\section{Introduction}

The genus Silene L. is one of the largest genera of flowering plants in the world (Bari, 1973). Silene L. (Caryophyllaceae) consists of about 700 species worldwide. These species are mainly distributed in the Northern hemisphere, Europe, Asia and Northern Africa (Bari 1973 and Greuter 1995). This genus is of particular interest in evolutionary and ecological studies, as highlighted by Bernasconi et al. (2009).

Silene species have been placed in 44 sections based on the characters of inflorescence, calyx (shape, hairiness and venation), shape of leaves, characters of capsule and seeds (Chowdhuri, 1957). Recently, molecular studies do not support such sectional classifications particularly for the endemic North American taxa (Oxelman and Liden 1995; Oxelman and Berglund 1997; Oxelman et al 2000; Burleigh and Holtsford 2003).

In Africa, Over 90 species are recorded, the vast majority in North Africa, with very few extending southwards into sub-Saharan Africa. Turrill (1956) and Wild (1961) recorded three native and one introduced species of Silene in the flora of south tropical Africa,

In Egypt, 29 species of Silene L. are distributed in the Mediterranean, Suez and Aqaba Gulfs, coastal plains in Sinai, the Nile Valley, Oases and Gebel Elba massive
(Täckholm, 1974 and Hosny et al., 1993). Out of these, 4 species, namely $S$. leucophylla, $S$. odontopetela, $S$. oreosinaica and $S$. schimperiana are endemic to Sinai, whereas $S$. biappendiculata is near-endemic in Egypt and Libya, Boulos (2009). In other words, the endemism ratio of Silene L. is $13.8 \%$ in Egypt.

In general, Silene species are annual, biennial, or perennial herbs. Diploid species, which are more frequent, have $2 n=18,20$ or 24 . Triploid, hexaploid and even higher polyploidy levels that have $2 n=c .96,120$ and 192, are also known in the genus (Swank 1932; Heaslip 1951; Bari 1973; Sopova and Sekovski 1982; Zhang 1994 and Oxelman et al. 1997), while $2 n=3 x=30$ is reported in S. fortunei (Heaslip, 1951). So, $x=9,10,12$ or 23 are the known basic chromosome numbers in Silene (Melzheimer 1978; 1988; Markova et al. 2006; Sheidai et al., 2011).

Many investigators in Iran and Turkey, where the species of Silene L. is more abundant, have made chromosome counting and karyological studies. Nine Silene species belong to section Sclerocalycinae grow in Iran, showed $2 n=2 x=24$ (Sheidai et al., 2009). Eighteen Silene L. species, subspecies and varieties belong to section Auriculatae showed $2 n=2 x=24$ in 9 species, $2 \mathrm{n}=4 x=48$ in 8 species and $2 n=6 x=72$ in 
Abbas El-Ghamery et al.

one species ( $S$. hirticalyx), Gholipour and Sheidai (2010a). Other studies showed $2 n=2 x=24,2 n=4 x=48$ and $2 n=8 x=96$ (Gholipour and Sheidai, 2010b; Gholipour et al., 2010; Sheidai_et al., 2011 and Atzazadeh et al., 2014). In turkey; the chromosome numbers of the investigated species counted $2 n=24$ and $x=12$ (Martin et al., 2008a; Martin et al., 2008b; Kiliç and Özçelik 2008; Yildiz et al., 2008; Minareci et al., 2009 and Yildizet al., 2009). Other studies in the worldwide showed $2 n=20,2 n=2 x=24$, $2 n=40,2 n=48$ (Luo D. et al., 2011; Rautenberg et al., 2012; Peruzziand Carta 2013; Draghia et al., 2013; Rani et al., 2014; Nersesian and Goukasian1995; Kamari et al., 2015; Jeelani et al., 2011 and Ghazanfar, 1983).

In Egypt, the only study on Silene L. was carried out by Badr et al.(1987) who recorded diploid number $2 n=24$ in four species viz. Silene succulenta, S. rubella, S. ligulata, and $S$. biappendiculata.

The present study was carried on the endemic species Silene schimperiana. This species is rare and endangered species, known from Sinai, Egypt; belongs to section: Sclerocalycinae (Hosny et al., 1993).

It is a perennial glaucous herb, woody at the base; stems $50-80 \mathrm{~cm}$, erect, rigid, branching, thicker at the nodes; lower leaves 4$10 \times 0.3-0.5 \mathrm{~cm}$, narrowly linear-spathulate, acute, with a prominent midrib on the lower surface; upper leaves shorter, narrowly linear; flowers in lax paniculate cymes, solitary or rarely 2 together, subtended by 2 minute bracteoles; pedicel $1.5-2 \mathrm{~cm}$; calyx $2.2-2.7 \mathrm{~cm}$, to $3 \mathrm{~cm}$ in fruit, 10-nerved, cylindric, glabrous, coriaceous; calyx-teeth 2-2.5 mm, dimorphic, triangular, acute $(2.5 \mathrm{~mm})$, and broadly triangular, obtuse $(2 \mathrm{~mm})$; petals 2-fid; capsule 1.3-1.5 cm, oblong, glabrous: carpophore equaling the capsule; seeds 1 x $1.5 \mathrm{~mm}$, deeply grooved. (Boulos 1999). Fig.1(a).

\section{Material and methods:}

Cytological studies were performed on 9 populations of Silene schimperiana: 1- Tinia, 2Abu Tweta, 3- Farsh Em Sella, 4- Shegif Em Sella, 5-Errommana, 6- Abu-Alie, 7 - Maarofia, 8- Abu-Qasaba and 9- Shag Saqr that are shown in Fig. 1 (b). These populations are named after their localities.

\section{Chromosome count and karyotype studies}

Seeds of Silene schimperiana were collected from natural habitats, Saint Catherine protectorate, South Sinai, Egypt. The seeds have been germinated in Petri dishes at room temperature in the laboratory. The root tips were soaked in $0.1 \%$ colchicine for 3 hours. Afterwards, the root tips were placed in fresh mixture of absolute alcohol: glacial acetic acid (3:1) for 24 hours in a refrigerator. Then the root tips were stored in $70 \%$ ethyl alcohol in a refrigerator until examination. The root tips were hydrolyzed in $1 \mathrm{~N} \mathrm{HCl}$ for 12 minutes at $60^{\circ} \mathrm{c}$. The root tips were stained according to Feulgen technique.

The counting, measuring of chromosomes lengths, and the karyotype analysis were taken place by using slides contain the chromosomes at the metaphase stage of the mitosis. The photographs, enlarged 9x60, were taken using a camera attached to the microscope. Only the slides with good spread and clearly observable morphologies are considered. Afterwards, the procedures for the location of the centromere, determination of the arm index, chromosome arms and total length, were conducted after the transfer of the images for the computer using karyotype 2 software (Altinordu et al., 2016).

\section{Karyotype description}

The chromosomes were identified according to Levan et al. (1964) as indicated in Table (1). Karyotype asymmetry (ST) was determined according to Stebbins (1971) as given in Table (2), while other karyotype parameters like haploid total chromosome length, mean chromosome length (Peruzzi et al., 2009), total form percentage (TF\%) (Huziwara, 1962), coefficient of variation of the centromeric index (CVCI) and coefficient of variation of the chromosome length (CVCL) (Paszko, 2006) as well as the intra-chromosomal asymmetry index (A1) and the inter-chromosomal asymmetry index (A2) (Romero-Zarco, 1986) were determined. The following formulae are used to calculate the TF, A1 and A2:

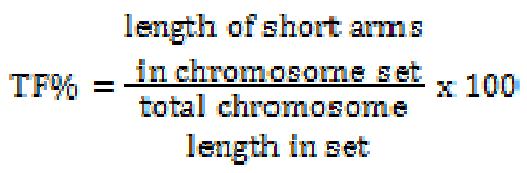


Chromosome count and karyotype study on endemic species Silene schimperiana.

$$
\mathbf{A}_{1}=1-\frac{\sum_{i=1}^{n} \frac{q_{i}}{p_{i}}}{n},
$$

Where qi is the mean length for short, and pi for long arms in every homologous chromosome pair or group; $\mathrm{n}$ is the number of homologous chromosome pairs or groups.

$$
\mathrm{A}_{2}=\frac{s_{C L}}{x_{C L}} .
$$

A2) is the ratio between the standard deviation $\left(\mathrm{S}_{\mathrm{CL}}\right)$ and the mean chromosome length $\left(\mathrm{X}_{\mathrm{CL}}\right)$.

\section{Statistical analysis}

For comparison between karyotypic features among different populations of $S$. schimperiana, we used Pearson's correlation coefficient by SPSS (Version 19), and principal components analysis PCA plot and Intrachromosomal asymmetry index (A1) against the inter-chromosomal asymmetry index (A2) by PC-ORD (Version 5.0) respectively. Primer (Version 7.0.11) was used to show the similarity of karyotype features in Hierarchical Cluster analysis and Non-metric Multi-Dimensional Scaling (nMDS).

\section{Results and Discussion}

The karyotype analyses showed that the chromosomes of studied populations of Silene schemperiana were $2 n=2 x=24$, Table (3) and Fig. (2). The chromosomes were mostly submetacentric. Anyhow, the 9 populations differed in their karyotype formulae. Six populations (Tinia, Shegif Em Sella, Errommana, Abu-Alie, Maarofia and Shag Saqr) had both meta submetacentric and sub-telocentric chromosomes; while two populations (Abu Tweta and AbuQasaba) had metacentric and sub-metacentric chromosomes. Meanwhile, only one (Farsh Em Sella) had sub-metacentric chromosomes.

The highest value of total and mean haploid chromosome lengths are recorded in Abu-Alie population (82.65 \& $6.89 \mu \mathrm{m}$, respectively). While, the lowest value of the same parameters occurred in Farsh Em Sella population (42.7 \& $3.47 \mu \mathrm{m}$, respectively). The size of the longest chromosome varied from $2.76 \mu \mathrm{m}$ in Farsh Em Sella population to $6.7 \mu \mathrm{m}$ in Abu-Alie population, Table (3).
The highest coefficient of Variation of Centromeric Index (CVCI) is 21.62 monitored in Abu-Alie population, while the lowest value (10.59) is monitored in Maarofia population. The highest Coefficient of Variation of Chromosome Length (CVCL) is 24.07 monitored in Shag Saqr population, while the lowest value (8.64) is monitored in Farsh Em Sella population. Total form percentage (TF\%) varied from 13.1 in Farsh Em Sella population to 33.37 in Maarofia population (Table, 3). The highest intrachromosomal asymmetry index (A1) is 0.64 recorded in $\mathrm{Abu}$ Tweta population, while the lowest value (0.5) in Maarofia population. The highest inter-chromosomal asymmetry index (A2) is 0.24 recorded in Shag Saqr population, while the lowest value (0.13) in Farsh Em Sella population (Table, 3 ).

The Pearson's correlation among the karyotype features (Table, 4) showed positive significant correlations between the total haploid length (THL), mean chromosome length, size of the longest chromosome (Correlation is significant at 0.01 level), the size of the shortest chromosomes and coefficient of Variation of Chromosome Length (CVCL) at the 0.05 level. In addition, the size of the longest chromosomes showed positive significant correlations with mean chromosome lengths at the 0.01 level. As well as, the size of the shortest chromosomes and the inter-chromosomal asymmetry indices (A2) at 0.05 level. The arm ratio (L/S) showed positive significant correlations with three asymmetrical indices CVCL, A1 and A2 at 0.05 level. In addition, there were other positive significant correlations between CVCL and A2 at 0.01 level. Mean chromosome lengths showed positive significant correlations with the size of the longest chromosomes at 0.01 level, and with the size of the shortest chromosomes at 0.05 level.

PCA analysis (data not given) showed that the first 2 axes comprised about $78 \%$ of the total variation. In the first axis with about $56 \%$ of total variance. The intra-chromosomal symmetry index (A1) and the inter-chromosomal asymmetry index (A2) were the most variable characters (Fig. 5). 
Abbas El-Ghamery et al.
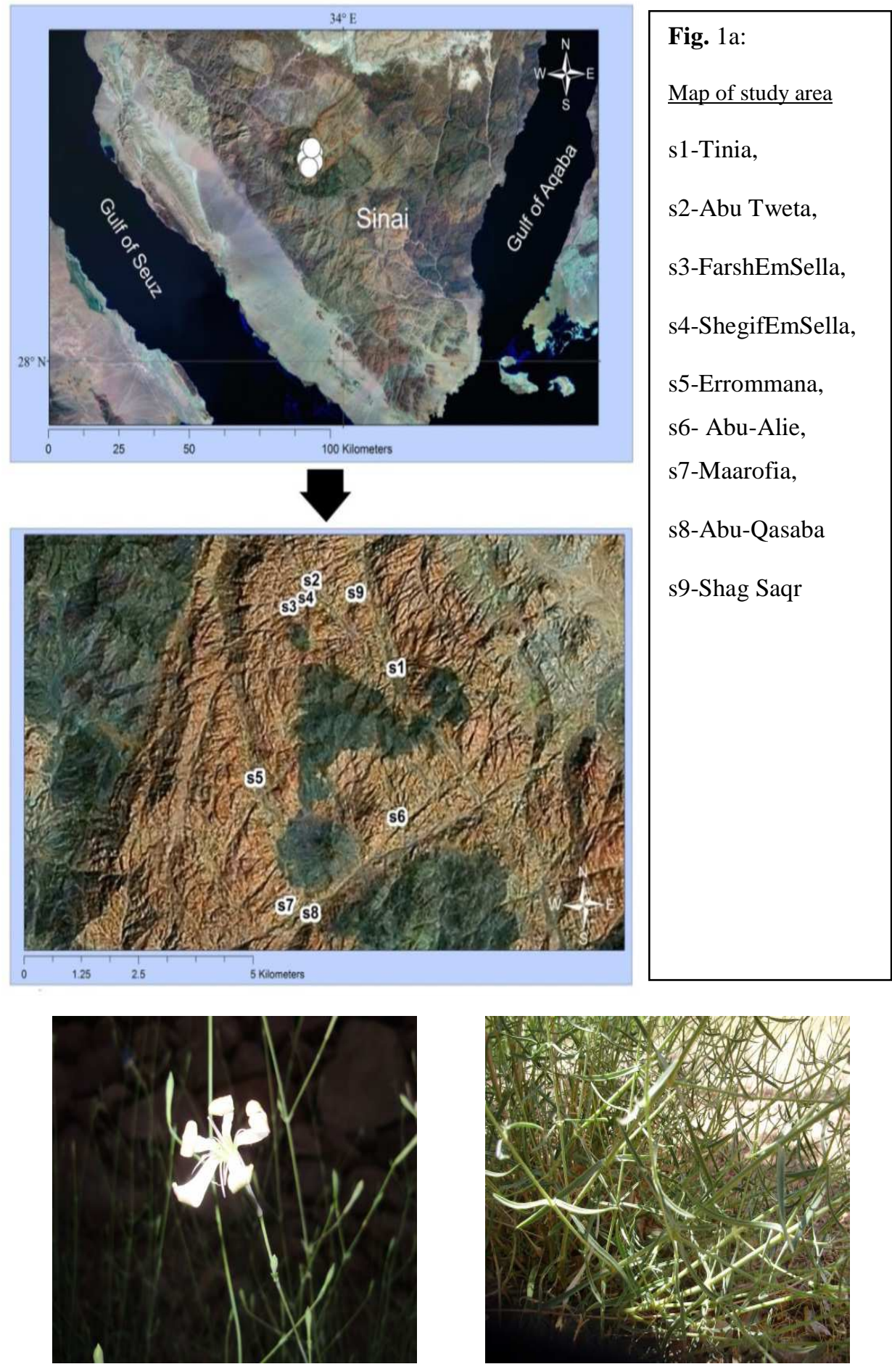

Figure 1b: Silene schimperiana photo from Sinai, Egypt 
Chromosome count and karyotype study on endemic species Silene schimperiana.

Table 1. Karyotype formula according (Levan et al., 1964)

\begin{tabular}{|c|c|c|c|c|c|}
\hline Term & Centromeric & Arm ratio & Cl $\times 100$ & \multicolumn{2}{|c|}{ Chromosome designation } \\
\hline M & Median point & 1 & 50 & \multirow{5}{*}{ 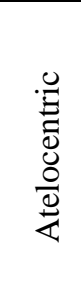 } & \multirow{2}{*}{ Metacentric $^{1}$} \\
\hline M & Median region & $1-1.7$ & $50-39.5$ & & \\
\hline $\mathrm{Sm}$ & Submedian region & $1.7-3$ & $39.5-25$ & & Submetacentric \\
\hline $\mathrm{St}$ & Subterminal region & $3-7$ & $25-12.5$ & & Subtelocentric \\
\hline $\mathrm{T}$ & Terminal region & $7-\infty$ & $12.5-0$ & & Acrocentric \\
\hline $\mathrm{T}$ & Terminal point & $\infty$ & 0 & & Telocentric \\
\hline
\end{tabular}

${ }^{1}$ Not a recommended term.

Table 2. The classification of karyotypes in relation to their degree of asymmetry according to Stebbins (1971)

\begin{tabular}{|c|c|l|c|c|}
\hline \multirow{2}{*}{$\begin{array}{c}\text { Ratio } \\
\text { L/S }\end{array}$} & \multicolumn{4}{|c|}{ Proportion of chromosomes with arm ratio<2:1 } \\
\cline { 2 - 5 } & $\mathbf{1 . 0 0 ( 1 )}$ & $\mathbf{0 . 9 9 - \mathbf { 0 . 5 1 } ( 2 )}$ & $\mathbf{0 . 5 0 - 0 . 0 1 ( 3 )}$ & $\mathbf{0 . 0 0 ( 4 )}$ \\
\hline$<2: 1(\mathrm{~A})$ & 1A & 2A & $3 \mathrm{~A}$ & $4 \mathrm{~A}$ \\
\hline $2: 1-4: 1(\mathrm{~B})$ & 1B & 2B & $3 \mathrm{~B}$ & $4 \mathrm{~B}$ \\
\hline$>4: 1(\mathrm{C})$ & 1C & $2 \mathrm{C}$ & $3 \mathrm{C}$ & $4 \mathrm{C}$ \\
\hline
\end{tabular}

Table 3. Karyotype features in the populations studied of Silene shimperiana. For abbr.: THL = Total chromosome length, $\mathrm{L}=$ Longest chromosome, $\mathrm{S}=$ Shortest chromosome, Ratio $(\mathrm{L} / \mathrm{s})=$ Longest $/$ shortest chromosome, $\mathrm{X}=$ Mean chromosome length, A1 and A2 =Romero-Zarco indices, TF = Total form percentage, Coefficient of Variation of Centromeric Index (CVCI) and Coefficient of Variation of Chromosome Length (CVCL).

\begin{tabular}{|c|l|c|c|c|c|c|c|c|c|}
\hline Loc Code & Location & $\mathrm{x}$ & $2 \mathrm{n}$ & $\mathrm{THL}$ & $\mathrm{L}(\mu \mathrm{m})$ & $\mathrm{S}(\mu \mathrm{m})$ & $\mathrm{L} / \mathrm{S}$ & $X(\mu \mathrm{m})$ & $\mathrm{TF} \%$ \\
\hline S1 & Tinia & 12 & 24 & 57.04 & 4.08 & 0.81 & 5 & 4.75 & 30.05 \\
\hline S2 & Abu Tweta & 12 & 24 & 43.83 & 3.36 & 0.45 & 7.5 & 3.65 & 26.38 \\
\hline S3 & FarshEmSella & 12 & 24 & 41.7 & 2.76 & 0.74 & 3.7 & 3.47 & 13.1 \\
\hline S4 & ShegifEmSella & 12 & 24 & 79.87 & 5.7 & 1.02 & 5.6 & 6.66 & 30.79 \\
\hline S5 & Errommana & 12 & 24 & 77.27 & 5.55 & 1.04 & 5.3 & 6.44 & 29.59 \\
\hline S6 & Abu-Alie & 12 & 24 & 82.65 & 6.7 & 1.05 & 6.4 & 6.89 & 27.69 \\
\hline S7 & Maarofia & 12 & 24 & 49.12 & 3.4 & 0.79 & 4.3 & 4.09 & 33.37 \\
\hline S8 & Abu-Qasaba & 12 & 24 & 72.51 & 6.64 & 1 & 6.6 & 6.04 & 29.27 \\
\hline S9 & Shag Saqr & 12 & 24 & 70.98 & 5.48 & 0.69 & 7.9 & 5.92 & 30.88 \\
\hline
\end{tabular}


Abbas El-Ghamery et al.

\begin{tabular}{|c|l|c|c|c|c|c|c|}
\hline Loc Code & Location & CVCI & CVCL & A1 & A2 & ST & Karyotype formula \\
\hline S1 & Tinia & 17.56 & 15.82 & 0.57 & 0.16 & $3 \mathrm{~B}$ & $2 \mathrm{~m}+7 \mathrm{sm}+3 \mathrm{st}$ \\
\hline S2 & Abu Tweta & 19.72 & 14.85 & 0.64 & 0.15 & $3 \mathrm{~A}$ & $6 \mathrm{sm}+6 \mathrm{st}$ \\
\hline S3 & FarshEmSella & 17.1 & 8.64 & 0.51 & 0.13 & $2 \mathrm{~A}$ & $12 \mathrm{sm}$ \\
\hline S4 & ShegifEmSella & 16.77 & 14.46 & 0.56 & 0.14 & $3 \mathrm{~A}$ & $3 \mathrm{~m}+8 \mathrm{sm}+1 \mathrm{st}$ \\
\hline S5 & Errommana & 17.58 & 16.87 & 0.57 & 0.17 & $3 \mathrm{~B}$ & $2 \mathrm{~m}+7 \mathrm{sm}+3 \mathrm{st}$ \\
\hline S6 & Abu-Alie & 21.62 & 21.91 & 0.61 & 0.22 & $3 \mathrm{~B}$ & $1 \mathrm{~m}+4 \mathrm{sm}+7 \mathrm{st}$ \\
\hline S7 & Maarofia & 10.59 & 13.94 & 0.5 & 0.14 & $3 \mathrm{~A}$ & $2 \mathrm{~m}+9 \mathrm{sm}+1 \mathrm{st}$ \\
\hline S8 & Abu-Qasaba & 15.14 & 22.49 & 0.58 & 0.22 & $3 \mathrm{~B}$ & $9 \mathrm{sm}+3 \mathrm{st}$ \\
\hline S9 & Shag Saqr & 18.75 & 24.07 & 0.56 & 0.24 & $3 \mathrm{~B}$ & $2 \mathrm{~m}+7 \mathrm{sm}+3 \mathrm{st}$ \\
\hline
\end{tabular}
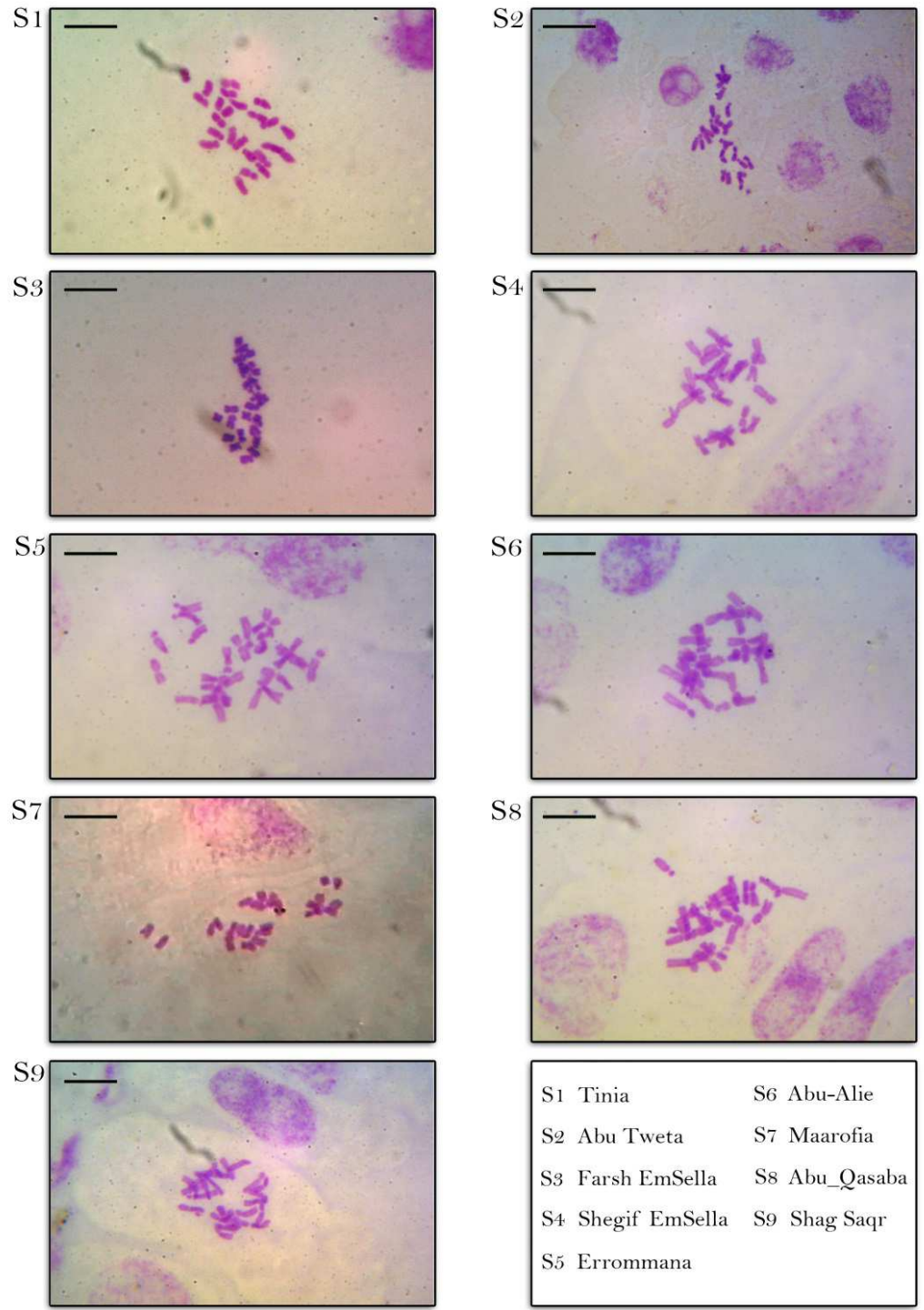

\begin{tabular}{|c|c|}
\hline S1 Tinia & S6 Abu-Alie \\
\hline Se Abu Tweta & S7 Maarofia \\
\hline S3 Farsh EmSella & S8 Abu_Qasaba \\
\hline S4 Shegif EmSella & S9 Shag Saqr \\
\hline S5 Errommana & \\
\hline
\end{tabular}

Fig. 2. Mitotic metaphase chromosomes of Silene schimperiana. Scale bar $=10 \mu \mathrm{m}$ 

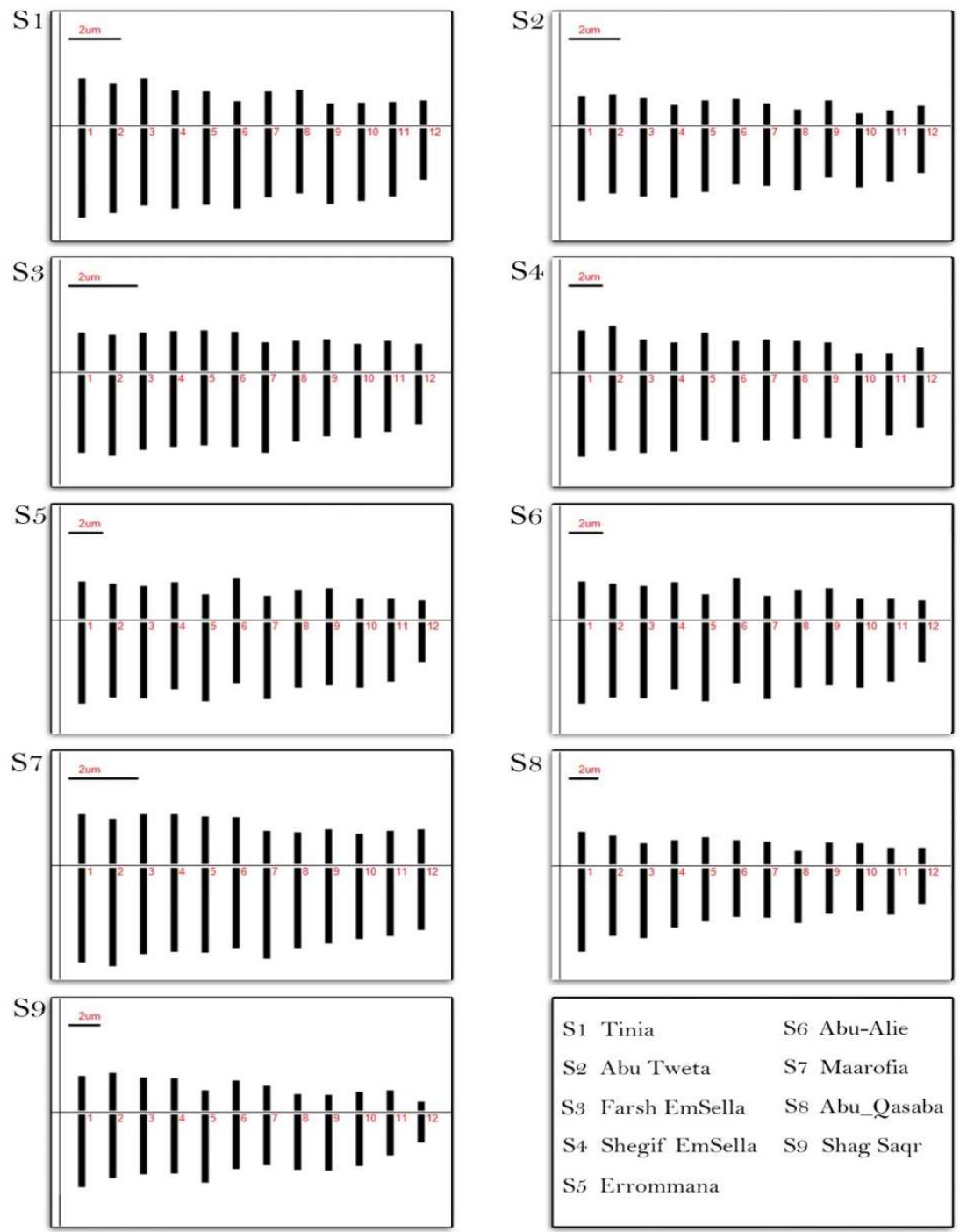

\begin{tabular}{|c|c|}
\hline S1 Tinia & S6 Abu-Alie \\
\hline S2 Abu Tweta & S7 Maarofia \\
\hline S3 Farsh EmSella & S8 Abu_Qasaba \\
\hline S4 Shegif EmSella & S9 Shag Saqr \\
\hline S5 Errommana & \\
\hline
\end{tabular}

Fig. 3. Representative ideograms of karyotypes in the nine populations of Silene schimperiana. Scale bar is different.

In our study Silene schimperiana, section Sclerocalycinae, is reported for the first time in Egypt with chromosome number counts for $2 \mathrm{n}=2 x=24$ and this result supports those of Sheidai et al. (2009) on nine species of silene in Iran. Also, it supports the results of Yildiz et al. (2009) that reported $2 \mathrm{n}=24$ and $x=12$ for fifteen taxa of Silene sect. Sclerocalycinae from Turkey.

Pearson's correlation gave significant correlation between mean chromosome lengths, size of the longest chromosomes and size of the shortest chromosomes; this is in line with the conducted by Gholipour and Sheidai (2010b). Therefore, the significant quantitative change in the chromosomes could be occurred in the size of both chromosomes arms during the species diversification.

PCA plot of Silene schimperiana based on karyotypic data, Fig. (4) supports the clustering results. PCA also showed that $\mathrm{A} 1$ and $\mathrm{A} 2$ are the most variable characters and accordingly we have made A1 against A2. 
Abbas El-Ghamery et al.

Fig. (5) showed the intra-chromosomal asymmetry index (A1) against the interchromosomal asymmetry index (A2). It is obvious that showed that Abu-Alie, Abu-Qasaba and Shag Saqr populations are separated in a group, while the other populations in the other one. The latter is subdivided into two subgroups, one of them includes Farsh Em Sella and Maarofia populations, while the other includes Tinia, Abu Tweta, Shegif Em Sella and Errommana populations. Also, a same division is recorded in the Hierarchical Cluster analysis and
Non-metric Multi-Dimensional Scaling (nMDS), Figs. (6) \& (7). The studied nine populations were separated into two main groups with similarity $92 \%$ (Fig. 6). Although the high similarity values between the studied $S$. schimperiana populations (Fig. 6), there are differences between the karyotype characters. These differences may be due to the occurrence of different ecotypes for $S$. schimperiana that needs further study on wide range of populations.

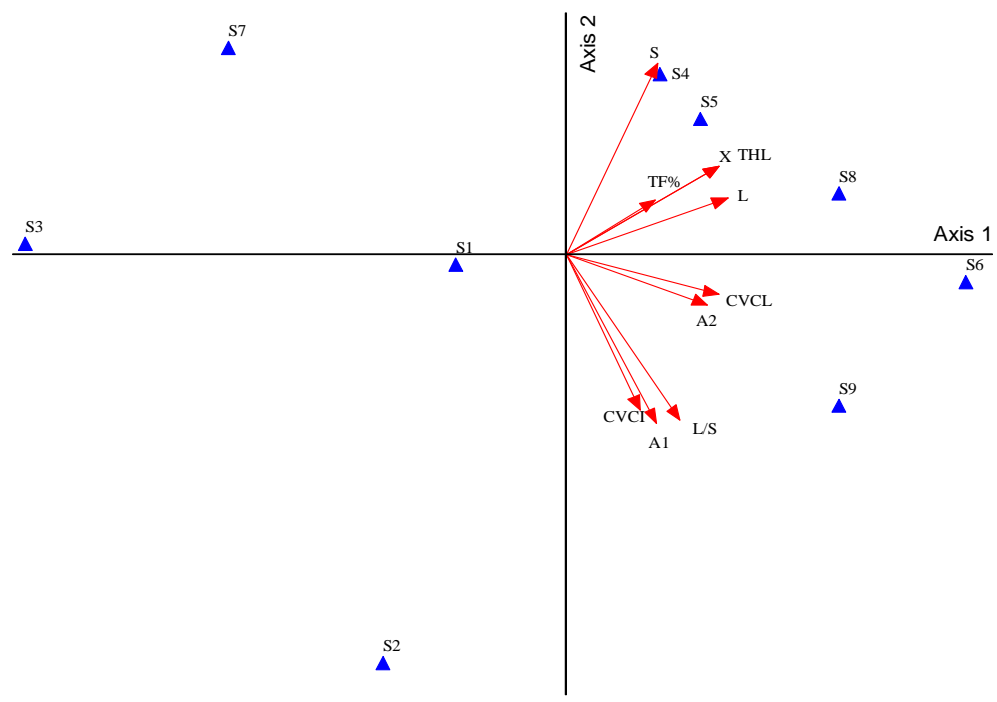

Figure 4. PCA plot of Silene species based on karyotypic data. Species code as in Table (3).

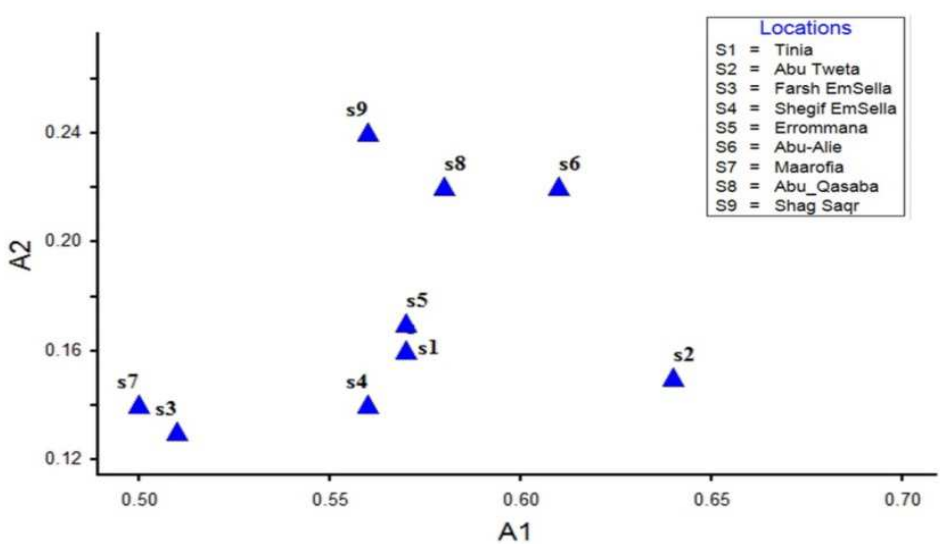

Fig. 5. Two-dimensional plot based on intra-chromosomal asymmetry index (A1) against the interchromosomal index (A2). 
Chromosome count and karyotype study on endemic species Silene schimperiana.

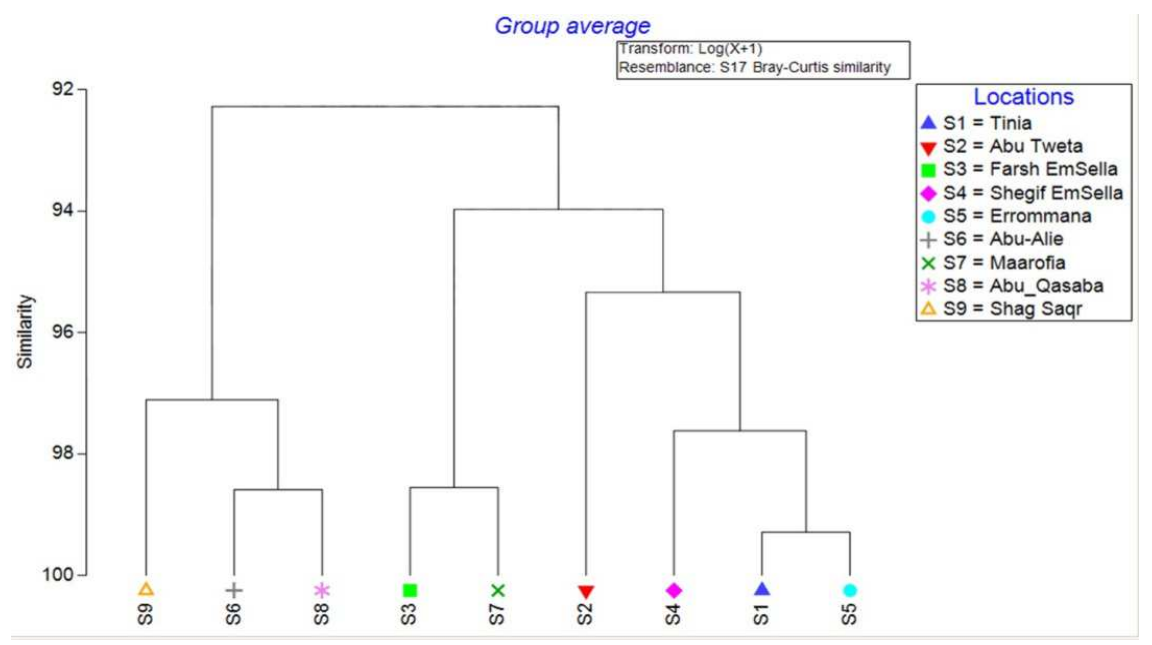

Figure 6. Hierarchical Cluster analysis in the studied populations of Silene schimperiana

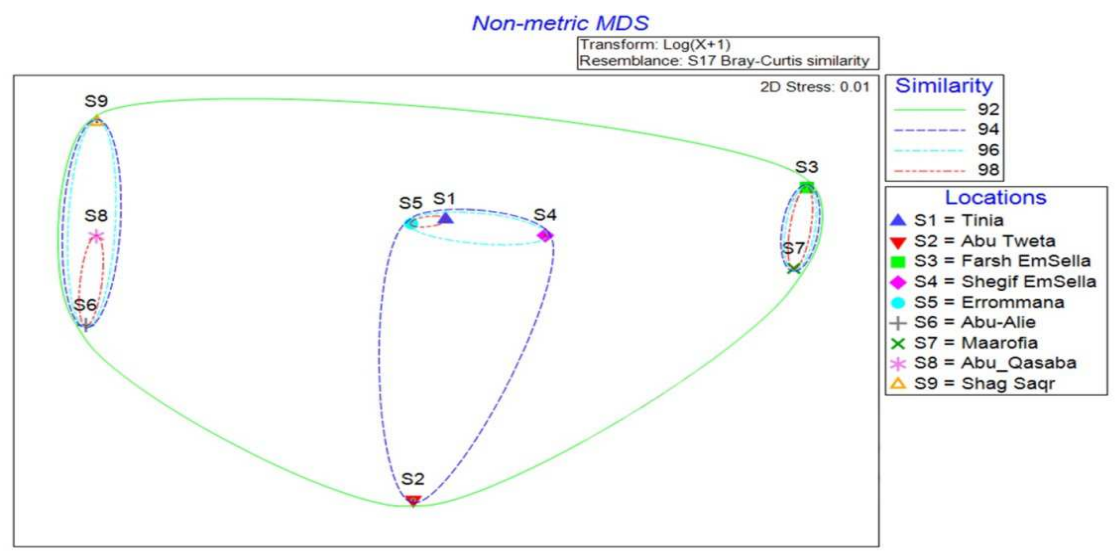

Figure 7. Non-metric Multi-Dimensional Scaling (nMDS) in the studied populations of Silene schimperiana populations. 
Abbas El-Ghamery et al.

Table 4. Pearson's coefficient of correlation among karyotype parameters, for abbreviations, see table (3).

\begin{tabular}{|c|c|c|c|c|c|c|c|c|c|c|c|}
\hline & & THL & $\begin{array}{c}\mathbf{L} \\
(\boldsymbol{\mu m})\end{array}$ & $\underset{(\mu \mathrm{m})}{S}$ & $\mathbf{L} / \mathbf{S}$ & $\underset{(\mu \mathbf{m})}{\mathbf{X}}$ & CVCI & CVCL & TF\% & A1 & A2 \\
\hline \multirow{3}{*}{ THL } & $\begin{array}{c}\text { Pearson's } \\
\text { Correlation }\end{array}$ & 1 & $\underline{.948^{* *}}$ & $\underline{.795^{*}}$ & .351 & $\underline{1.000^{* * *}}$ & .304 & $\underline{.674^{*}}$ & .476 & .279 & .600 \\
\hline & $\begin{array}{l}\text { Sig. (2- } \\
\text { tailed) }\end{array}$ & & .000 & .010 & .355 & .000 & .426 & .047 & .195 & .467 & .088 \\
\hline & $\mathrm{N}$ & 9 & 9 & 9 & 9 & 9 & 9 & 9 & 9 & 9 & 9 \\
\hline \multirow{3}{*}{$\begin{array}{c}\mathbf{L} \\
(\boldsymbol{\mu m})\end{array}$} & $\begin{array}{c}\text { Pearson's } \\
\text { Correlation }\end{array}$ & $\underline{.948^{* *}}$ & 1 &. $.732^{*}$ & .479 & $.947^{* * *}$ & .304 & $\underline{.804^{* * *}}$ & .447 & .387 & $.747^{*}$ \\
\hline & $\begin{array}{l}\text { Sig. (2- } \\
\text { tailed) }\end{array}$ & .000 & & .025 & .192 & .000 & .427 & .009 & .228 & .303 & .021 \\
\hline & $\mathrm{N}$ & 9 & 9 & 9 & 9 & 9 & 9 & 9 & 9 & 9 & 9 \\
\hline \multirow{3}{*}{$\underset{(\mu \mathrm{m})}{S}$} & $\begin{array}{c}\text { Pearson's } \\
\text { Correlation }\end{array}$ & $.795^{*}$ & $\underline{.732^{*}}$ & 1 & -.241 & $\underline{.795^{*}}$ & -.057 & .277 & .242 & -.113 & .240 \\
\hline & $\begin{array}{l}\text { Sig. (2- } \\
\text { tailed) }\end{array}$ & .010 & .025 & & .533 & .010 & .883 & .470 & .530 & .772 & .535 \\
\hline & $\mathrm{N}$ & 9 & 9 & 9 & 9 & 9 & 9 & 9 & 9 & 9 & 9 \\
\hline \multirow{3}{*}{$\mathbf{L} / \mathbf{S}$} & $\begin{array}{c}\text { Pearson's } \\
\text { Correlation } \\
\end{array}$ & .351 & .479 & -.241 & 1 & .351 & .524 & $.760^{*}$ & .367 &. $.734^{*}$ & $\underline{.705^{*}}$ \\
\hline & $\begin{array}{l}\text { Sig. (2- } \\
\text { tailed) }\end{array}$ & .355 & .192 & .533 & & .354 & .147 & .017 & .332 & .024 & .034 \\
\hline & $\mathrm{N}$ & 9 & 9 & 9 & 9 & 9 & 9 & 9 & 9 & 9 & 9 \\
\hline \multirow{3}{*}{$\underset{(\mu \mathrm{m})}{\mathbf{X}}$} & $\begin{array}{c}\text { Pearson's } \\
\text { Correlation }\end{array}$ & $\underline{1.000^{* *}}$ & $\underline{.947^{* *}}$ & $\underline{.795^{*}}$ & .351 & 1 & .305 &. $.674^{*}$ & .476 & .279 & .600 \\
\hline & $\begin{array}{l}\text { Sig. (2- } \\
\text { tailed) }\end{array}$ & .000 & .000 & .010 & .354 & & .425 & .047 & .195 & .467 & .088 \\
\hline & $\mathrm{N}$ & 9 & 9 & 9 & 9 & 9 & 9 & 9 & 9 & 9 & 9 \\
\hline \multirow{3}{*}{ CVCI } & $\begin{array}{c}\text { Pearson's } \\
\text { Correlation } \\
\end{array}$ & .304 & .304 & -.057 & .524 & .305 & 1 & .307 & -.257 & $.732^{*}$ & .379 \\
\hline & $\begin{array}{l}\text { Sig. (2- } \\
\text { tailed) }\end{array}$ & .426 & .427 & .883 & .147 & .425 & & .422 & .505 & .025 & .314 \\
\hline & $\mathrm{N}$ & 9 & 9 & 9 & 9 & 9 & 9 & 9 & 9 & 9 & 9 \\
\hline \multirow{3}{*}{ CVCL } & $\begin{array}{c}\text { Pearson's } \\
\text { Correlation } \\
\end{array}$ & $.674^{*}$ & $\underline{.804^{* *}}$ & .277 & $.760^{*}$ & $\underline{.674^{*}}$ & .307 & 1 & .547 & .447 & $\underline{.962^{* * *}}$ \\
\hline & $\begin{array}{l}\text { Sig. (2- } \\
\text { tailed) }\end{array}$ & .047 & .009 & .470 & .017 & .047 & .422 & & .127 & .228 & .000 \\
\hline & $\mathrm{N}$ & 9 & 9 & 9 & 9 & 9 & 9 & 9 & 9 & 9 & 9 \\
\hline \multirow{3}{*}{ TF\% } & $\begin{array}{c}\text { Pearson's } \\
\text { Correlation }\end{array}$ & .476 & .447 & .242 & .367 & .476 & -.257 & .547 & 1 & .168 & .317 \\
\hline & $\begin{array}{l}\text { Sig. (2- } \\
\text { tailed) }\end{array}$ & .195 & .228 & .530 & .332 & .195 & .505 & .127 & & .666 & .406 \\
\hline & $\mathrm{N}$ & 9 & 9 & 9 & 9 & 9 & 9 & 9 & 9 & 9 & 9 \\
\hline \multirow{3}{*}{ A1 } & $\begin{array}{c}\text { Pearson's } \\
\text { Correlation } \\
\end{array}$ & .279 & .387 & -.113 & $.734^{*}$ & .279 & $\underline{.732^{*}}$ & .447 & .168 & 1 & .371 \\
\hline & $\begin{array}{l}\text { Sig. (2- } \\
\text { tailed) }\end{array}$ & .467 & .303 & .772 & .024 & .467 & .025 & .228 & .666 & & .326 \\
\hline & $\mathrm{N}$ & 9 & 9 & 9 & 9 & 9 & 9 & 9 & 9 & 9 & 9 \\
\hline \multirow{3}{*}{ A2 } & $\begin{array}{c}\text { Pearson's } \\
\text { Correlation } \\
\end{array}$ & .600 &. $.747^{*}$ & .240 & $.705^{*}$ & .600 & .379 & $.962^{* *}$ & .317 & .371 & 1 \\
\hline & $\begin{array}{l}\text { Sig. (2- } \\
\text { tailed) }\end{array}$ & .088 & .021 & .535 & .034 & .088 & .314 & .000 & .406 & .326 & \\
\hline & $\mathrm{N}$ & 9 & 9 & 9 & 9 & 9 & 9 & 9 & 9 & 9 & 9 \\
\hline
\end{tabular}

* Correlation is significant at the 0.05 level (2-tailed).

** Correlation is significant at the 0.01 level (2-tailed). 
Chromosome count and karyotype study on endemic species Silene schimperiana.

\section{Acknowledgements}

I'm greatly indebted to Prof. Dr. Abbas Ahmed El-Ghamery for guidance at all parts of the study, his continuous follow up at all steps starting from the visit of field till the end of writing this article.

\section{References}

Altinordu, F, X., Peruzzi, L., Yu, Y. and He, X. (2016). A tool for the analysis of chromosomes: Karyotype Taxon 65(3): 586-592. Atzazadeh, N., Keshavarzi, M., Sheidai, M. and Gholipour, A. (2014). Morphological and karyotype diversity in populations of four Silene species (caryophyllaceae). Acta Biologica Szegediensis, 58(1): 27-37.

Badr, A., Hamoud, M. A. and Elkington, T. T. (1987). Cytology and taxonomic relationships of some taxa in the genus Silene L. Cytologia, 52(1): 63-68.

Bari, E. A.(1973). Cytological Studies in the Genus Silene L. New Phytologist, 72(4): 833838.

Bernasconi, G. Antonovics, J. Biere, A. Charlesworth, D.Delph, L.F. Giraud, T. Hood, M.E. Marais, G.A.B. McCauley, D. Pannell, J.R. Shykoff, J.A. Vyskot, B. Wolfe, L.M. and Widmer, A. (2009). Silene as a model system in ecology and evolution. Heredity, 103(1): 5-14.

Boulos, L. (1999). Flora of Egypt (Vol. 1). Cairo: Al Hadara Publishing Cairo.

Boulos, L.(2009). Flora of Egypt Checklist, Revised Annotated Edition. Cairo: Al Hadara Publishing Cairo.

Burleigh, J. G. and Holtsford, T. P.(2003). Molecular systematics of the Eastern North American Silene (Caryophyllaceae): evidence from nuclear ITS and chloroplast trnL intron sequences. Rhodora, 105: 76-90.

Chowdhuri, P. K.(1957). Studies in the genus Silene. Notes from the Royal Botanic Garden, Edinburgh, 22: 221-278.

Draghia, L., Chelariu, E. L., Sîrbu, C., Brênzê, M. andMiculschi, C. S. (2013). Analysis of chromosome number in some Allium and Silene wild species with ornamental use. Notulae Botanicae Horti Agrobotanici ClujNapoca, 41(1): 294-300.
Ghazanfar, S. A.(1983). Cytological Studies in the Genus Silene L. New Phytologist, 93(1): 123-127.

Gholipour, A. and Sheidai, M. (2010a). Karyotype analysis and new chromosome number reports in Silene species (sect. Auriculatae, Caryophyllaceae). Biologia, 65(1): 23-27.

Gholipour, A. and Sheidai, M. (2010b). Further contribution to cytotaxonomy of the genus Silene L.(sect. Auriculatae, Caryophyllaceae). Acta Biologica Szegediensis, 54(2): 111-115.

Gholipour, A., Sheidai, M.andMozaffarian, V.(2010). A taxonomic study of Silene goniocaula (Caryophyllaceae) complex in Iran. Rostaniha, 11(1): 83-86.

Greuter, W. (1995). Silene (Caryophyllaceae) in Greece: a subgeneric and sectional classification. Taxon, 44: 543-581.

Heaslip, M. B. (1951). Some cytoecological aspects in the evolution of certain species of the plant genus Silene. Ohio J. Sci., 51: 62-70.

Hosny, A. I., El Hadidi, M. N. and Shamso, E. (1993). Taxonomic studies of Silenoideae (Caryophyllaceae) in Egypt: 1. Systematic revision of the genus Silene L. Taeckholmia, 14: $1-36$.

Huziwara, Y. (1962). Karyotype analysis in some genera of Compositae. VIII. Further studies on the chromosomes of Aster. American Journal of Botany, 49: 116-119.

Jeelani, S. M., Rani, S., Kumar, S., Kumari, S. and Gupta, R. C.(2011). Meiotic studies in some members of Caryophyllaceae Juss. from the Western Himalayas. Acta Biologica Cracoviensia Series Botanica, 53(1): 86-95.

Kamari, G., Blanche, C. and Siljak-Yakovlev, S. (2015). Mediterranean chromosome number reports-25-Flora Mediterranea 25:143-167.

Kiliç, S. and Özcelik, H. (2008). Taxonomic revision of Silene L. sect.Brachypodae (Boiss.) Chowdhuri (Caryophyllaceae). International Journal of Natural and Engineering Sciences, 2(2): 59-63.

Levan, A., Fredga, K. and Sandberg, A. A. (1964). Nomenclature for centromeric position on chromosomes. Hereditas, 52(2): 201-220.

Luo, D., Liu, D., Xu, B., Nie, Z.-L., Sun, H. and Li, Z.-M.(2011). A karyological study of six species of Silene L.(Caryophyllaceae) from the Hengduan Mountains, SW China. Caryologia, 64(1): 10-13. 
Abbas El-Ghamery et al.

Markova, M., Lengerova, M., Zluvova, J., Janousek, B. and Vyskot, B. (2006). Karyological analysis of an interspecific hybrid between the dioecious Silene latifolia and the hermaphroditic Silene viscosa. Genome, 49(4): 373-379.

Martin, E., Duran, A., Dinç, M. and Öztürk, M. (2008a). Karyotype analysis of Silene salsuginea Hub.-Mor. and Silene doganii A. Duran and Y. Menemen Local Endemic to for Turkey. Journal of Applied Biological Sciences, 2(3): 65-68.

Martin, E., Duran, A., Dinç, M. and Öztürk, M. (2008b). Karyotype analysis of Silene behen L. (Caryophyllaceae). J. Appl. Biol. Sci, 2(1): 13-15.

Melzheimer, V. (1978). Notes on cytology of several species of the genus Silene (Caryophyllaceae) from central Greece and from Crete. plant systematics and evolution, 130(3-4): 203-207.

Melzheimer, V.(1988). Caryophyllaceae in flora Iranica. Rechinger KH. Akademische Druck-U. Verlagsanstalt, Graz, Austria, 163: 353-508.

Minareci, E., Yildiz, K. and Çirpici, A. (2009). Karyological studies in some species of the genus Silene (Caryophyllaceae). Cytologia, 74(3): 245-252.

Nersesian, A. A.andGoukasian, A. G.(1995). On the karyology of the representatives of the genus Silene L. sl (Caryophyllaceae) from Southern Transcaucasia. Thaiszia, 5(1): 13-19.

Oxelman, B.andLiden, M. (1995). Generic boundaries in the tribe Sileneae (Caryophyllaceae) as inferred from nuclear rDNA sequences. Taxon, 44: 525-542.

Oxelman, B., Liden, M.andBerglund, D.(1997). Chloroplast rps16 intron phylogeny of the tribe Sileneae (Caryophyllaceae). Plant Syst Evol., 206: 411-420.

Oxelman, B., Liden, M., Rabeler, R. and Popp, M. (2000). A revised generic classification of the tribe Sileneae (Caryophyllaceae). Nordic Journal of Botany, 20(6): 743-748.

Paszko, B.(2006). A critical review and a new proposal of karyotype asymmetry indices. Plant Systematics and Evolution, 258(1-2): 39-48.

Peruzzi, L. and Carta, A.(2013). A taxonomic revision of Silene nocturna species complex (Caryophyllaceae) in Italy. Phytotaxa, 88(3): 3848.
Peruzzi, L., Leitch, I. J. and Caparelli, K. F. (2009). Chromosome diversity and evolution in Liliaceae. Annals of Botany, 103(3): 459-475.

Rani, S., Kumari, S., Gupta, R. C.andChahota, R. K.(2014). Cytological studies of Angiosperms (174 species) from District Kangra, Himachal Pradesh (India). Plant systematics and evolution, 300(5): 851-862.

Rautenberg, A., Sloan, D. B., Aldén, V. and Oxelman, B. (2012). Phylogenetic relationships of Silene multinervia and Silene section Conoimorpha (Caryophyllaceae). Systematic Botany, 37(1): 226-237.

Romero-Zarco, C. (1986). A new method for estimating karyotype asymmetry. Taxon, 35: 526-530.

Sheidai, M., Eftekharian, R., Gholipoor, A. and Noormohammadi, Z.(2011). Population diversity and polyploidy incidence in 3 Silene species. A cytological approach. Cytologia, 76(4): 395-402.

Sheidai, M., Enayatkhani, M., Bahmani, F. and Gholipour, A. (2009). Cytological study in the genus Silene (sect. Sclerocalycinae). Cytologia, 74(4): 437-442.

Sopova, M. and Sekovski, Z. (1982). Chromosome atlas of some Macedonian angiosperms III. God. Zborn. Biol. Fak. Univ. Kiril Metodij, 35: 145-160.

Stebbins, G. L. (1971). Chromosomal evolution in higher plants. Edward Arnold, London.

Swank, G. R. (1932). The Ethnobotany of the Acoma and Laguna Indians. MA Thesis, University of New Mexico.

Täckholm, V. (1974). Students' Flora of Egypt. $2^{\text {nd }}$ ed. Cairo University, Egypt.

Turrill, W. B.(1956). Silene. In W.B. Turrill and E. Milne-Redhead, Flora of tropical East Africa (Caryophyllaceae). Crown Agents for Oversea Governments and Administrations London.

Wild, H. (1961). Silene. In A.W. Exell and H. Wild, Flora zambesiaca. Crown Agents for Oversea Governments and Administrations, London.

Yildiz, K., Minareci, E. and Cirpici, A.(2009). A karyotypic study on Silene sect. Sclerocalycinae in Turkey. Nordic Journal of Botany, 27(6): 503-509.

Yildiz, K., Minareci, E., Cirpici, A. and Dadandi, M. Y. (2008). A karyotypic study on Silene, section Siphonomorpha species of 
Chromosome count and karyotype study on endemic species Silene schimperiana.

Turkey. Nordic Journal of Botany, 26(5-6): 368374.
Zhang, Y.(1994). Studies on chromosome of some plants from Guandi Mountain, Shanxi. Wuhan botanical research, 12(3): 201-206. 